\title{
MCM/CSP基板のファインパターン化はどこまで可能か
}

\author{
佐々木 淳*
}

\section{How Far Could We Go with High Density MCM/CSP Substrate?}

Jun SASAKI*

*凸版印刷株式会社エレクトロニクス事業本部（テ104-0028 東京都中央区八重洲2-2-7）

*Electronics Div. ,Toppan Printing Co., Ltd. (2-2-7 Yaesu, Chuo-Ku, Tokyo 104-0028)

\section{1.はじめに}

マルチメディア環境の急速な一般化に伴い, コンピュー 夕にはネットワークと画像, 音声等への対応が必須となり, クライアントマシンではモバイル化を究極とした小型化と 高性能化への要求がますます高まっている。また，サーバ ではマルチメディアデータベースの具現化等, さらなる飛 躍的な高速化要求が目前に迫っている。この大きなトレン ドを背景として, LSIの実装技術に，今，大きな変革が始 まっている。LSIの高機能化, とりわけ高速化が多ピン化 をもたらし, 高密度化であるシュリンク化と相まって, ベ アチップとパッケージとの各々に実装用パッドレイアウト の狭ピッチ化やエリアアレイ化への変化を促しているので ある。そのため, パッケージをなくしてしまうというべア チップ実装化と, パッケージをベアチップ（ベアダイ）と 同じぐらいまで小型化しょうとするコンセプトである CSP (Chip Size/Scale Package) とが登場してきた。

さらに，それぞれのレベルで，エリアアレイ化が進み始 めている。

パッケージ実装では, 従来のQFPのようなペリフェラ

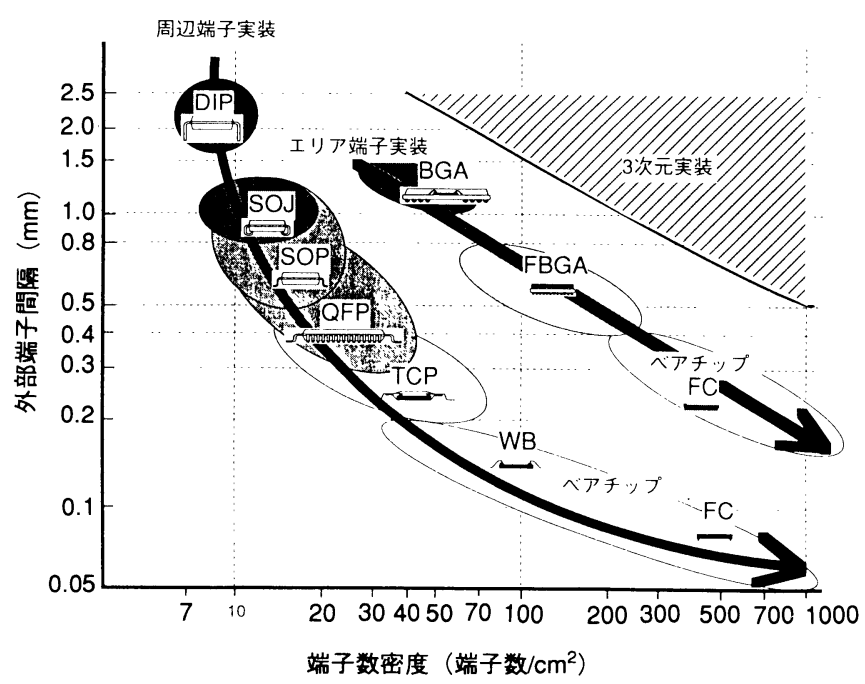

図1. 半蕒体高密度実装の勤向
ルタイプのパッケージからPGA, BGA/LGAが増え, ベア チップ実装でも, ワイヤボンディング(WB)実装からフリ ップチップ(FC)実装へと向かい始めている1。

このような変化の中でMCM（Multi Chip Module）は, KGDのみならず，各種デバイスを集中的にまとめ，局所 的な高密度化と高速対応を実現するための概念として位置 づけられ始めている。図 $1 ， 2^{21}$ に示すように，これまで にも似たような概念はあったが，その高機能化や狭ピッチ 化を具現化するための技術とインフラは新しく，業界構造 への影響は必至である。その実装対応のための配線板への 要求仕様は飛躍的に厳しくなっており, 従来の工法による 配線板の標準仕様では実現が困難となりつつある。

ここでは，このような新しい要求に対応したサブストレ ートとして，ビルドアップ（D/L）配線板によるファイン 化の現状と今後の見通しについて紹介する。

\section{MCM/CSP基板への要求仕様}

2. 1 ファイン化要求

高密度, かつ高速対応の観点から今後想定される実装方
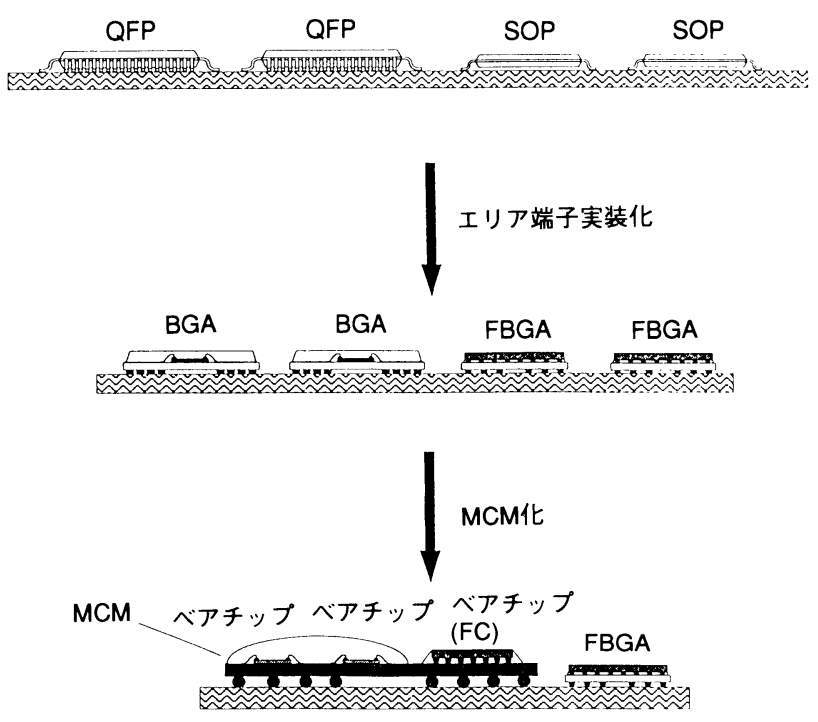

図2. 半真体パッケージとベアチップの実装例 
式として，FC実装とCSP実装があげられる。CSP（Chip Size/Scale Package) は, EIAJが, FBGA/LGAと呼ぶ小 型パッケージの規格にほほ相当する。また, 最近, FC実 装のCSPも発表され始めており, 今後の発展が見达まれる゙”。

FC実装するべアチップには, ペリフェラル型とエリア アレイ型の 2 種類が想定され, 要求仕様が異なる。表 1 に それぞれの場合に配線板に要求される先端仕様の例を示し た。ワイヤボンデイング用のデバイスを流用することの多 いペリフェラル型の場合は, 配線板でのライン/スペース よりもパッド/スペースの方が狭ピッチとなり, 現状で $50 / 50 \mu \mathrm{m}$ 以下， $85 \mu \mathrm{m}$ ピッチ程度を想定する必要がある。

エリアアレイ型では, ソルダレジスト(SR)とパッドとの 大きさと配置にもよるが,パッド間に配線を通すためには,

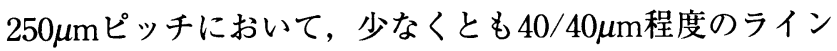
/スペースが必要となる。後者の仕様はCSPのよりファイ ンピッチ化したものとみなすこともできる。たとえば, 0.5mmピッチのCSPにおいて，そのパッドをピッチの半分 と仮定し $250 \mu \mathrm{m}$, さらにSRをパッド上にかぶせ, アライ メント公差を仮に $\pm 50 \mu \mathrm{m}$ とした場合で $350 \mu \mathrm{m}$ となり，パ

表1．高密度実装(FC/CSP)のための配線板仕様

単位.： $\mu \mathrm{m}$

\begin{tabular}{l|c|c|c}
\hline \multirow{2}{*}{} & \multirow{2}{*}{$\begin{array}{c}\text { ペフェラル } \\
\mathrm{FC}\end{array}$} & \multicolumn{2}{|c}{ エリアアレイ } \\
\cline { 3 - 4 } & FC & CSP \\
\hline パッドピッチ & $85(40 / 45)$ & $250(130 / 120)$ & $\begin{array}{c}500(350 / 150) \\
\text { SR開口径=250 }\end{array}$ \\
\hline ラインノスペース & $50 / 50$ & $<40 / 40$ & $\begin{array}{l}50 / 50 \text { (ライン間に1 本) } \\
30 / 30 \text { (ライン間に2 本) }\end{array}$ \\
\hline ビアノランド & $80 / 150$ & $80 / 130$ & $80 / 150$ \\
\hline
\end{tabular}

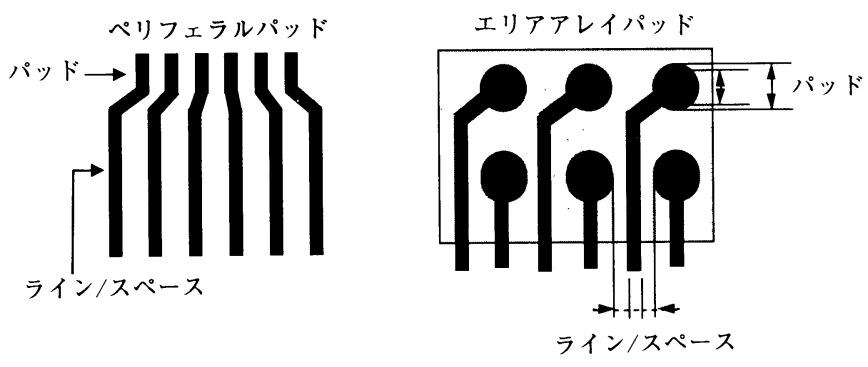

ッド間に一本のラインを通すために50/50 $\mu \mathrm{m}$ 以下のライン /スペースのルールが必要となる。

\section{2 基板表面への要求}

ベアチップ実装には, 各社より様々な接続方法が提案さ れている。主な方法を図 3 に示す2)。

一般に,狭ピッチ要求の多いペリフェラルでは金バンプ, またエリアアレイでは，はんだバンプが用いられることが 多い。

しかしながら，現状ではそれぞれの接続方法に基板の表 面仕上げ要求が必ずしも 1：1に対応しない。各社の考え 方によりその仕様は異なる。表 2 に示すように，銅，無電 解金，はんだ等がある。また，その厚みにより対応できる 工法が制限される。

\section{3. 配線板仕様の現状と課題}

表 3 に,プラスチック系配線板の代表的な仕様を比較し て示した。

SMT用PWBは, 通常のガラスエポキシ材を用いたプリ ント配線板の仕様である。IVH代替ビルドアップは, 通常 のPWB用の装置を流用した場合のビルドアップ工法によ る仕様の例である。ライン/スペースは, SMT用PWBに 比べIVH構造にもかかわらず，ややファイン化する。導体 層の構成が, 通常はめっきのみであるため, 銅箔にスルー ホール用めっきをするSMT用PWBに比べて銅の厚さが薄 くなり，ファイン化しやすくなるからである。したがって 銅䈃をラミネートして形成するシート状のビルドアップで は, 孔の導通がめっきの場合, SMT用PWBと同様の条件 となる。また，アライメント方法が基本的に同じなので,

表2. 各実装方法と基板に要求される仕様の比較

\begin{tabular}{c|c|l}
\hline 要求特性 & WB & \multicolumn{1}{|c}{ FC } \\
\hline 表面仕上げ & 厚付け金めっき & $\begin{array}{l}\text { 薄付け金めった } \\
\text { はんた } \\
\text { 銅 (防錆处理等) }\end{array}$ \\
\hline 平坦性 & 許容度大 & $\begin{array}{l}10 〜 20 \mu \mathrm{m} \text { 以内 } \\
\text { (実装方法により異なる) }\end{array}$ \\
\hline 熱彭張率特性 & 許容度大 & $\begin{array}{l}\text { インタポーザと } \\
\text { して最適化必要 }\end{array}$ \\
\hline
\end{tabular}

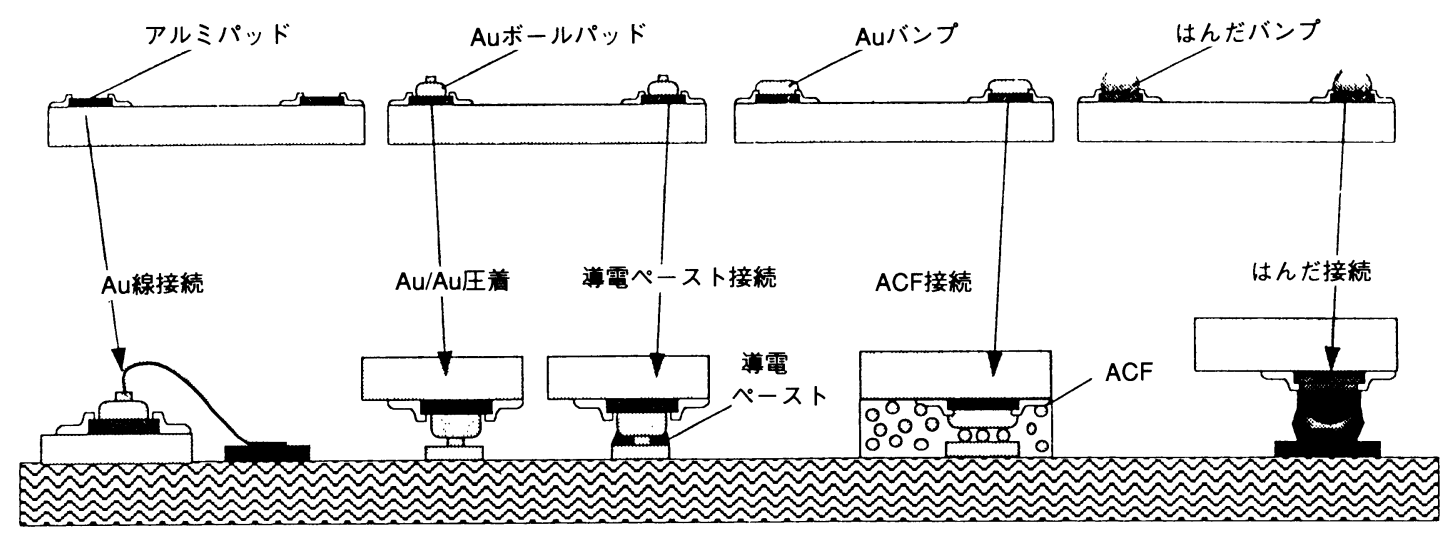

図3. ベアチップ実装におけるボンディングパッド樓造とその対応接続方法 
表3. プラスチック系配線板仕様の比較

単位: $\mu \mathrm{m}$

\begin{tabular}{|c|c|c|c|c|}
\hline & \multirow{2}{*}{ SMT用PWB } & \multirow{2}{*}{ IVH代替ビルドアップ } & \multicolumn{2}{|c|}{ T-MD/L (Toppan Micro Deposit on Laminata) } \\
\hline & & & Grade- II & Grade- III \\
\hline パッドピッチ & $\begin{array}{c}300-500 \\
(150 / 250)\end{array}$ & $\begin{array}{c}100-200 \\
(50 / 75 \text { std. })\end{array}$ & $\begin{array}{c}\min .85 \\
(30 / 55 \text { std. })\end{array}$ & $\begin{array}{c}\min .85 \\
(40 / 45 \text { std. })\end{array}$ \\
\hline ラインノスペース & $\begin{array}{c}200-300 \\
(100 / 100)\end{array}$ & $\begin{array}{c}100-150 \\
(75 / 75 \text { std. })\end{array}$ & $\begin{array}{c}80-100 \\
(50 / 50 \text { std. })\end{array}$ & $\begin{array}{c}60-100 \\
(40 / 40 \mathrm{std} .)\end{array}$ \\
\hline ビアノランド & $300 / 500$ & $100-150 / 300$ & $80 / 130$ & $80 / 130$ \\
\hline ビア形成方法 & ドリル & フォトリソ/レーザ & フォトリソ & フォトリソ \\
\hline 層の構成 & コア材+プリプレグ & $\mathrm{D} 1 / \mathrm{Ln} / \mathrm{D} 1^{*}$ & $\mathrm{D} 3 / \mathrm{Ln} / \mathrm{D} 3^{*}$ & $\mathrm{D} 3 / \mathrm{Ln} / \mathrm{D} 3 *$ \\
\hline
\end{tabular}

* D; Deposit, L; Laminate; PWBの耐側に各数字:の層数をビルドアップ

表4. $\mathrm{PWB}$ と T-MD/Lの工法の比較

\begin{tabular}{|c|c|c|c|}
\hline & & PWB & T-MD/X \\
\hline \multirow[t]{4}{*}{ 絶縁層 } & \multirow[t]{2}{*}{ 材料 } & ガラスエポキシ & エポキシ系十フィラー \\
\hline & & シート状 & 液状 \\
\hline & 多層化 & 具突プレス & コーティング \\
\hline & 孔形成方法 & ドリル & $\begin{array}{l}\text { フォトリソグラフィ } \\
\text { ファインアライメントマーク }\end{array}$ \\
\hline \multirow[t]{5}{*}{ 配線層 } & 材料 & 釦（無禹解, 電解） & 銅（無電解，電解） \\
\hline & \multirow[t]{2}{*}{ 工法 } & \multirow[t]{2}{*}{ サブトシクティブ } & サブトラクティブ（Grade- II） \\
\hline & & & セミアディティブ（Grade-III） \\
\hline & レジスト & ドライフィルムタイブ & $\begin{array}{l}\text { 液体 } \\
\text { ファインアライメントマーク }\end{array}$ \\
\hline & 原版 & フィルムマスク & ガラスマスクノフィルムマスク \\
\hline
\end{tabular}

ランド径から孔径を引いた值が両者でほぼ近い值となる。 結果的には小径ランドを比較的容易に得ることができる。 なお, ビルドアップ層間のアライメントが困難である等の 理由により，通常はコアとなる基材の両側に 1 層ずつであ ることが多い。

しかしながら,これらの仕様では, 先に示した先端の仕 様を満たすことはできない。

T-MD/L (TOPPAN Micro Deposit on Laminate) は, 著者らが開発したビルドアップ（D/L）基板である。 Grade-II とGrade-III とでは, 配線関連の工法が異なり仕様

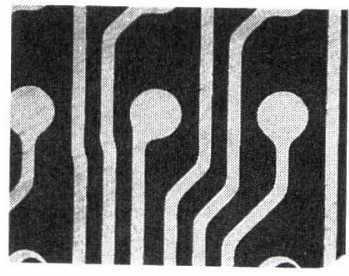

平面写真

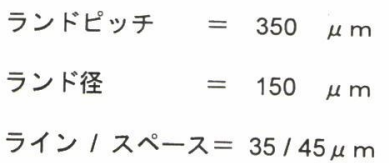

$(45 / 35 / 45 / 35 / 45)$
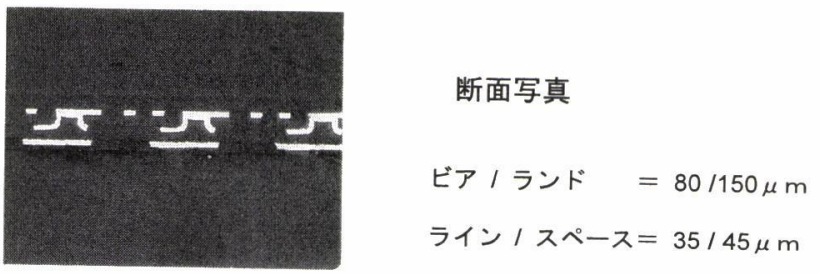

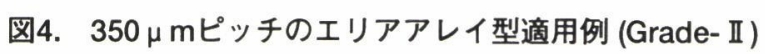

が異なるが，いずれも，ほほ要求仕様を満たしていること がわかる。T-MD/Lと通常のPWBとの工法の比較を表4に 示した。これらの実施により, 小径のフォトビアとファイ ンなアライメントマークによる自動露光系の組み合わせ で，小径ランドを得ることができた。また，原版，レジス ト，エッチング装置等の総合的な見直しを行い, サプトラ

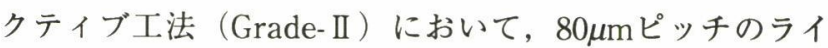
ン/スペースが達成できた。図 4 に, Grade-II を $350 \mu \mathrm{m} ヒ ゚$ ッチのエリアアレイ型に適用した例を示す。また, 図 5 に Grade- III を $85 \mu \mathrm{m}$ ピッチのペリフェラル型に適用した例を

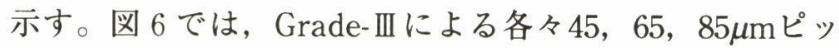
チ形成の例を示した。このように，セミアディティブ工法

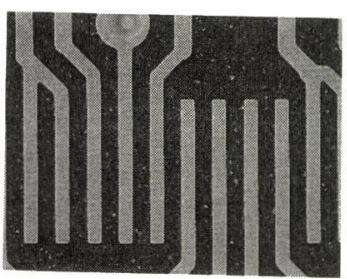

\section{平面写真}

ラインピッチ $\quad=\quad 85 \mu \mathrm{m}$ ライン / スペース $=40 / 45 \mu \mathrm{m}$

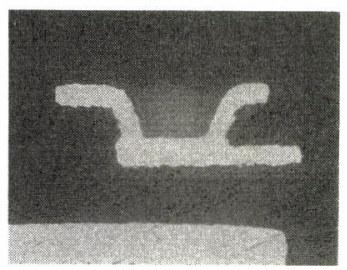

\section{断面写真}

ビア/ランド $\quad=80 / 150 \mu \mathrm{m}$

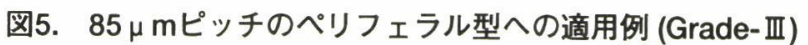




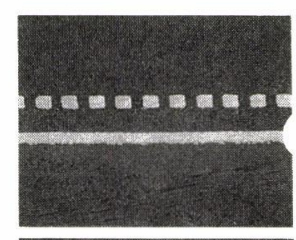

$$
\begin{aligned}
& \text { ラインピッチ }=45 \mu \mathrm{m} \\
& \text { ライン / スペース }=25 / 20 \mu \mathrm{m}
\end{aligned}
$$

ラインピッチ $=65 \mu \mathrm{m}$

ライン / スペース $=35 / 30 \mu \mathrm{m}$

ラインピッチ $=85 \mu \mathrm{m}$

ライン / スペース $=45 / 40 \mu \mathrm{m}$

図6. セミアディティブエ法によるファインピッチ配線の 形成例 (Grade-II)

による配線形成により，20 $\mathrm{m}$ のライン幅が原理的に可能 となる。今後, 信頼性特性と特性インピーダンスを考慮し た絶縁層の厚さと配線幅の最適化が必要となる。

\section{4. $\mathrm{MCM} / \mathrm{CSP}$ 基板の信頼性}

これまで示したように，T-MD/Lをはじめとする

$\mathrm{MCM} / \mathrm{CSP}$ 基板は，通常のプリント配線板に比べ, 配線の 狭ピッチ化, 孔とランドの小径化, 絶縁層の薄膜化などに より, 高密度化が一挙に進行している。また, ガラス䄉維 を使用しなくなるなど材質面でも変化しており, 低電圧化 など仕様環境も異なる。したがって, 従来のプリント配線 板とは異なる信頼性評価が必要と考えられる。

現状で要求される代表的な試験条件と判定基準の例を表 5 に示す。このように, 基板単体に対して要求される評価 方法と条件は, LSIパッケージとプリント配線板に由来す る評価方法との狭間にあり, また, 前処理の条件, 試験の 環境条件, 印加電圧条件, 判定基準において各々異なる要 求となっている。

信頼性評価方法の標準化が早急に必要である。

すなわち, MCM用などの新たな使用環境と使用される 機器への要求を考慮した上で, 対応する故障モードと加速 係数を見直し, 信頼性の評価方法を再設定していく必要が あろう。

表 6 にT-MD/Lの信頼性評価結果を示した。

\section{5. まとめ}

ここでは新たなマーケットにおいてMCM/CSP基板に要 求される仕様とその対応例を示した。さらに, 今後もマル

表5. 高密度配線板の信頼性評価試験の例

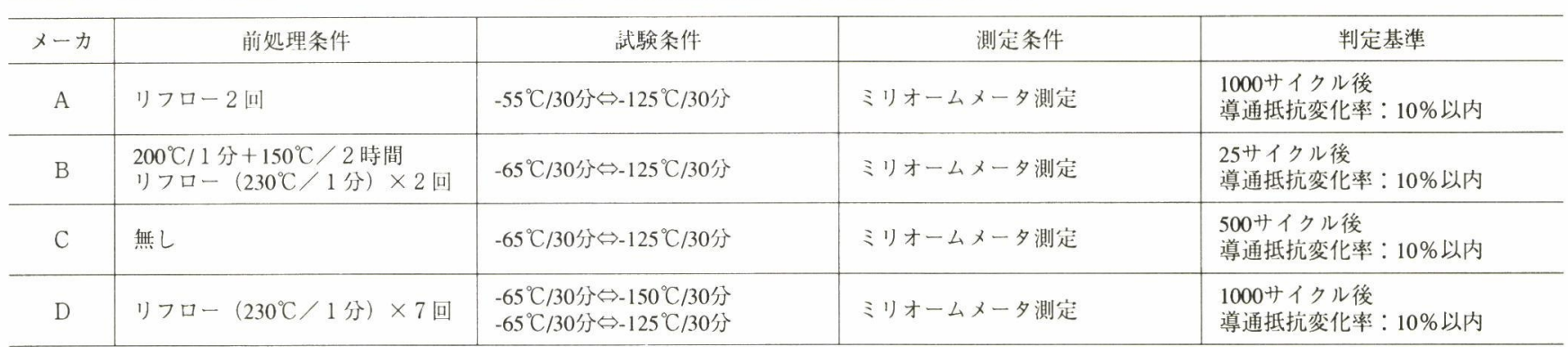

\begin{tabular}{|c|c|c|c|c|}
\hline メーカ & 前処理条件 & 武験条件 & 測定条件 & 判定基準 \\
\hline A & 無し & $85^{\circ} \mathrm{C} / 85 \% \mathrm{RH} \quad 20 \mathrm{~V}$ 印加 & 6 時間每: $50 \mathrm{~V} に て$ & 絶縁抵抗 $>10^{8} \Omega$ \\
\hline $\mathrm{B}$ & $110^{\circ} \mathrm{C} / 2$ 時間 & $60^{\circ} \mathrm{C} / 85 \%$ RH 20V印地 & 連続測定 & 250 時間後 絶縁抵抗 $>10^{8} \Omega$ \\
\hline $\mathrm{C}$ & 無し & $85^{\circ} \mathrm{C} / 85 \% \mathrm{RH}$ 12V印的 & 6 分每 $50 \mathrm{~V} / 1$ 分 & 1000 時間後 絶縁抵抗 $>10^{8} \Omega$ \\
\hline $\mathrm{D}$ & リフロー $\left(230^{\circ} \mathrm{C} / 1\right.$ 分 $) \times 7$ 回 & $85^{\circ} \mathrm{C} / 85 \% \mathrm{RH} \quad 5 \mathrm{~V}$ 印加 & 連続測定 & 1000 時間後 絶縁抵抗 $>10^{8} \Omega$ \\
\hline
\end{tabular}

試験名：絶縁信頼性評価試験

表6. 信頼性評価結果

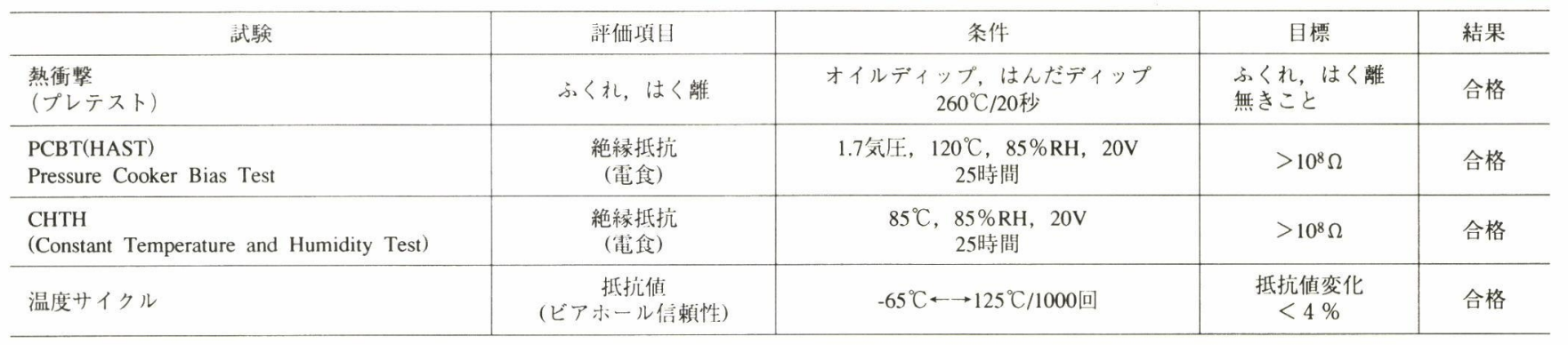


チメディア機器にはバンド幅拡幅のためにバス幅の拡大と バス速度の高速化とが必要であり, 配線板には一層の高密 度化と, 高速化への対応が要求される。MPU内部のクロ ック周波数の劇的な向上と高速メモリの普及環境を考慮す ると, 配線板の高速化対応への要求はこれからが本番とも いえる。

高速特性と機械強度に優れたプラスチック系配線板への 期待は大きい。しかしながら，これまでのガラスエポキシ 系では, 装置の一般化と共に低価格化は相当進んだが, 仕 様は限界に近い。すなわち, 現状の標準的な工法ではこの 新たな要求に答えるのは困難であり, T-MD/Lのような新 工法での製品仕様が必須になると考えられる。

さらに，この仕様を活かすためには，統合的な視点が必 要である。例えば, 基板の配線と部品配置を考慮した端子 レイアウトをデバイス，パッケージの段階から設計に織り 込むことで, 全体の作りやすさが変わる。また, 基板設計 では, デバイスの電気特性, 熱特性を考慮することが必要 となる。そのためのCAD，デザインキット，シミュレー ション技術に代表される環境の整備が必要である。このよ うなデバイス, 実装, 基板, セットメーカといった関係者
間の密接なコミュニケーションを促進することが, 成功の ための今後の課題である。

(1997.12.9-受理１998.1.26-再受理)

\section{文献}

1) Thomas Goodman and E. Jan Vardaman: "The Flip Chip Market”, Advanced Packaging ,Vol.6, No.5, pp.24-26,(1997)

2) $\mathrm{MCM} / \mathrm{KGD}$ 研究会：“MCM/KGD技術に関するロードマッ プ”，日本電子機械工業会，pp.6-7，（1997）

3) Ted Tessier, et al.: "Motorola's Fine Pitch Area Array Packaging Alternatives", Advancing Microelectronics, Vol.24, No.6, pp.8-13, (1997)

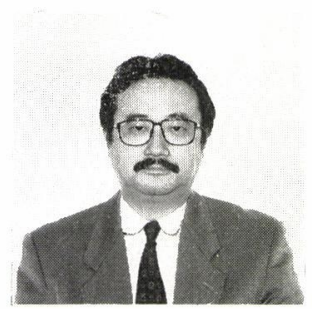

佐々木 淳 (ささきじゅん)

昭和 31 年生まれ。昭和 58 年, 東北大学大学 院工学研究科応用化学専攻修了。現在, 凸 版印刷株式会社エレクトロニクス事業本部 において, MCMや $\mathrm{SCM}$ 用途の $\mathrm{D} / \mathrm{L}$ 基板の 開発，販売促進に従事。 